Meta

Journal des traducteurs

Translators' Journal

\title{
A Structural Overview of Inuktitut
}

\section{Susan Sammons}

Volume 38, numéro 1, mars 1993

La traduction et l'interprétation dans le nord du Canada

Translation and Interpretation in Northen Canada

URI : https://id.erudit.org/iderudit/004022ar

DOI : https://doi.org/10.7202/004022ar

Aller au sommaire du numéro

\section{Éditeur(s)}

Les Presses de l'Université de Montréal

\section{ISSN}

0026-0452 (imprimé)

1492-1421 (numérique)

Découvrir la revue

\section{Citer cet article}

Sammons, S. (1993). A Structural Overview of Inuktitut. Meta, 38(1), 11-17. https://doi.org/10.7202/004022ar

\section{Résumé de l'article}

Ce survol structurel offre une description de l'inuktitut en tant que langue polysynthé-tique et agglutinante. On signale les liens entre l'inuktitut et les autres familles de langues et on dresse la liste des langues et dialectes qui y sont rattachés. On décrit également les systèmes phonologiques et morphophonologiques de cette langue. Enfin, la morphologie principale de la langue est discutée en deux sous-sections, l'une traitant du syntagme nominal, l'autre du syngtame verbal. d'utilisation que vous pouvez consulter en ligne.

https://apropos.erudit.org/fr/usagers/politique-dutilisation/ 


\section{SECTION I}




\title{
A STRUCTURAL OVERVIEW OF INUKTITUT
}

SUSAN SAMMONS

Arctic College, Iqaluit,

Northwest Territories, Canada

\begin{abstract}
Résumé
Ce survol structurel offre une description de l'inuktitut en tant que langue polysynthétique et agglutinante. On signale les liens entre l'inuktitut et les autres familles de langues et on dresse la liste des langues et dialectes qui y sont rattachés. On décrit également les systèmes phonologiques et morphophonologiques de cette langue. Enfin, la morphologie principale de la langue est discutée en deux sous-sections, l'une traitant du syntagme nominal, l'autre du syngtame verbal.
\end{abstract}

\begin{abstract}
This structural overview includes a brief discussion of Inuktitut as a polysynthetic agglutinative language. It outlines affiliations with other language families and lists the subbranches and dialects of the language. The phonological and morphophonemic systems of Inuktitut are described. The central morphology of the language is discussed in two subsections, one dealing with the noun phrase, the other with the verb phrase.
\end{abstract}

Eskimo-Aleut is a language family originally centered in Alaska, which has now spread across Northern Canada, Greenland and the north-eastern tip of Siberia. It probably has wider affiliations with Chukotko-Kamchatkan and Uralic although at present this is still uncertain. There are two branches of this family, Eskimo and Aleut, which are in turn composed of seven distinct languages.

\section{ESKIMO-ALEUT}

\begin{tabular}{lll}
\multicolumn{1}{c}{ ESKIMO } & & ALEUT \\
YUPIK & INUIT & ALEUT \\
Sirenikski & Inuit & Aleut \\
Central Alaska Yupik & & \\
Alutiiq & & \\
Naukanski & & \\
Central Siberian Yupik & &
\end{tabular}

The Inuit subbranch is composed of 16 dialects spread out over 8,000 kilometres from Little Diomede Island in the Bering Strait to the east coast of Greenland. It is spoken by approximately 66,000 people. This multiplicity of dialects further complicates the already difficult task of interpreting and translating in Canada's North. The lack of dictionaries and other resource material also aggravates this situation, as does the use of two orthographies, syllabic and roman.

The Inuit language can be described as polysynthetic in structure. It is agglutinative in so far as individual grammatical affixes can be segmented in invariant form, although upon closer examination, a certain amount of fusion occurs due to phonological processes. 
The phonemic system is fairly simple. There are three vowels $\mathbf{a}, \mathbf{i}$ and $\mathbf{u}$ which can be long or short. There are several single consonants $\mathbf{g}, \mathbf{h}, \mathbf{j}, \mathbf{k}, \mathbf{l}, \mathbf{m}, \mathbf{n g}, \mathbf{p}, \mathbf{n}, \mathbf{x}, \mathbf{q}, \mathbf{X}, \mathbf{s , t}, \mathbf{v}$ and several consonant cluster combinations, which vary somewhat from dialect to dialect.

The word is the core of the morphology. The word begins with a root to which affixes may be added, from a minimum of one up to six or more. Some affixes define the semantic content in detail while others express grammatical category.

Tautuqattaqujaulaunngitkaluaqtugut.

\begin{tabular}{|c|c|c|c|c|c|c|c|}
\hline $\begin{array}{l}\text { tautuk } \\
\text { root } \\
\text { (watch) }\end{array}$ & $\begin{array}{l}\text { - qattaq } \\
\text { habitual } \\
\text { action }\end{array}$ & $\begin{array}{l}-q u \\
\text { tell }\end{array}$ & $\begin{array}{l}\text {-jau } \\
\text { passive }\end{array}$ & $\begin{array}{l}\text {-lauq } \\
\text { general } \\
\text { past }\end{array}$ & $\begin{array}{l}\text {-nngit } \\
\text { negative }\end{array}$ & $\begin{array}{l}\text {-kaluaq } \\
\text { actually }\end{array}$ & $\begin{array}{l}\text {-tugut } \\
\text { indicative } \\
1 \mathrm{pl} \\
\text { intransitive }\end{array}$ \\
\hline
\end{tabular}

We were actually told not to keep watching.

Many morphophonemic alternations occur at these affix boundaries. Affixes can be divided into two categories: deleting and non-deleting.

Many affixes delete the final consonant of the stem.

Itilauqtuq.

$\begin{array}{lll}\text { itiq } & \text {-lauq } & - \text { thq } \\ \text { stem (enter) } & \text { general past } & 3 \text { sg indicative intransitive }\end{array}$

He came in.

With non-deleting affixes a mutually - influenced assimilation between the stem final consonant and the first segment of the affixes occurs and either one or both consonants may change.

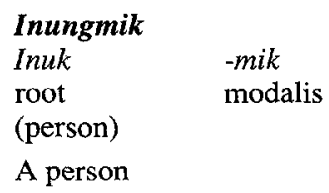

Before beginning this structural sketch of Inuktitut a few words of caution seem in order. The grammatical categories used in describing Indo-European languages such as nouns and verbs etc. should not be seen as absolute slots which can be successfully applied to label the phenomena of non Indo-European languages.

\section{THE NOUN PHRASE}

Nouns and pronouns in Inuktitut are inflected for number, person and case. Nouns and pronouns have no gender. The primary suffixes of number are the same in nouns and pronouns, $-\mathrm{q}$ or $\emptyset$ for singular, $-\mathrm{k}$ for dual and $-\mathrm{t}$ for plural. In Inuktitut, nouns in the third person are marked as to whether they are coreferent or non-coreferent with the subject of a controlling clause. These markers have been traditionally referred to as third and fourth person in the literature. The marking of third person subjects in this way is also known as switch reference.

\begin{tabular}{lllllll}
\multicolumn{2}{l}{ Quviasuttianngittuq } & katangmat. & & & & \\
quvia & - suk & - ttiaq & -nngit & $-t u q$ & katak & -mat \\
root & intransitive & adverb & negative & indicative & root & causative \\
(happy) & marker & (really) & & $3 s g$ & (fall) & 4 sg \\
& & & & intransitive & & intransitive
\end{tabular}

She is really sad because she falls. (Margaret) (Jane) 


\begin{tabular}{lllllll}
\multicolumn{2}{l}{ Quviasuttianngittuq } & katakkami & & & & \\
quvia & -suk & - ttiaq & - nngit & -tuq & katak & -gami \\
root & intransitive & adverb & negative & indicative & root & causative \\
(happy) & marker & (really) & & $3 \mathrm{sg}$ & (fall) & $3 \mathrm{sg}$ \\
& & & & intransitive & & intransitive
\end{tabular}

She is sad because she falls

(Margaret) (Margaret)

There are eight cases in Inuktitut: absolutive, relative, modalis, localis, ablative, vialis, terminalis and aequalis. The absolutive and relative cases are particularly interesting.

The absolutive case marks both the subject of an intransitive clause and the object of a transitive clause. This case lacks a special ending in the singular of unpossessed nouns.

\section{Arnaq tikittuq.}

$\begin{array}{ll}\text { arnaq } & -\phi \\ \text { root } & \text { absolutive } \\ \text { (woman) } & \end{array}$

The woman arrives.

$\begin{array}{ll}- \text { tikit } & - \text { tuq } \\ \text { root } & \text { indicative } \\ \text { (arrive) } & 3 \mathrm{sg} \\ & \text { intransitive }\end{array}$

\section{Arnaq takujara.}

$\begin{array}{llll}\text { arnag } & -\phi & \text { taku } & - \text { jara } \\ \text { root } & \text { absolutive } & \text { root } & \text { indicative } \\ \text { (woman) } & & \text { (see) } & \begin{array}{l}1 \text { sg } / 3 s g \\ \text { transitive }\end{array}\end{array}$

I see the woman.

The relative case marked by the suffix -(u)p indicates transitive subjects. The existence of this case is the reason for Inuktitut being classified by some as an ergative language. ${ }^{2}$

\section{Arnaup takujaanga. \\ arnaq -up taku -jaanga \\ root (woman) relative root (see) indicative $3 \mathrm{sg} / 1 \mathrm{sg}$ relative}

The woman sees me.

The relative case is also used to mark the possessor in possessive constructions. The possessor precedes the possessed which has a suffix that indicates the person, and number of the possessor and the case of the entire noun phrase.

$\begin{array}{llllll}\text { Nutaraup } & \text { qimmia takujara. } & & & \\ \text { nutaraq } & - \text { up } & \text { qimmiq } & -a & \text { taku } & \text {-jara } \\ \text { root } & \text { relative } & \text { root } & 3 \mathrm{sg} \text { abs } & \text { root (see) } & \text { indicative } \\ \text { (child) } & & \text { (dog) } & \text { possessed } & & 1 \mathrm{sg} / 3 \mathrm{sg} \text { transitive }\end{array}$

I see the child's dog.

Relative pronouns as such do not exist in Inuktitut. There are only three types of pronouns. The first type are independent, the second type are attached to nouns, and the third type are attached to verbs.

The first type typically occurs when the same person is both the subject and the object of a verb, and can be described as personal object pronouns or reflexives.

\section{Takuvunga uvamnik. \\ $\begin{array}{lll}\text { taku } & \text {-vunga } & \text {-yvamnik } \\ \text { root (see) } & \text { indicative 1sg } & 1 \text { sg modalis } \\ & \text { intransitive }\end{array}$}

I see myself.

This type also occurs with demonstrative pronouns/adverbs (spatial deictics) which are quite explicit. Denny $(1982)^{3}$ has described this system of deictic spatial adverbs as involving contrasts of "here/there" with five locations. These are expressed by eleven 
roots. Each root can take the prefix ta-[C] to express things that cannot be seen or pointed to (or to indicate that the referent has already been referred to), yiclding twenty-two prefixed roots. Each of these can take four local case suffixes yielding eighty-eight words.

The second type which are attached to nouns, creates a possessed form of the noun. Case may be added after these suffixes.

Nulianga.

nuliaq

root

$-n g a$

(wife)

possessive

His wife.

The third type are subject pronouns which are always suffixed to the verb in both transitive and intransitive clauses.

Takuvunga tuktumik.

$\begin{array}{llll}\text { taku } & \text {-vunga } & \text { tuktu } & - \text { mik } \\ \text { root } & \text { indicative } & \text { root } & \text { modalis } \\ \text { (see) } & 1 \text { sg intransitive } & \text { (caribou) } & \end{array}$

I see the caribou.

Qimmirmik tusaqtunga.

$\begin{array}{llll}\text { qimmiq } & - \text { mik } & \text { tusaq } & \text { tunga } \\ \text { root (dog) } & \text { modalis } & \text { root (hear) } & \text { indicative 1sg intransitive }\end{array}$

I hear the dog.

When the same pronoun is not both subject and object of a verb, the person pronoun object may be combined with the subject pronoun and suffixed to the verb in transitive clauses.

Takuvara.

taku

root

(see)

I see it.

-vara
indicative
$1 \mathrm{sg} / 3 \mathrm{sg}$ intransitive

indicative
$1 \mathrm{sg} / 3 \mathrm{sg}$ intransitive
Tusaqtara.

$\begin{array}{ll}\text { tusaq } & \text {-tara } \\ \text { root } & \text { indicative } \\ \text { (hear) } & 1 \mathrm{sg} / 3 \mathrm{sg} \text { transitive }\end{array}$

\section{THE VERB PHRASE}

Pronoun suffixes attached to verbs indicate the transitivity, mood, person and number of the verb phrase. Person and number operate the same in verbs as they do in nouns.

There are three types of verb phrases in Inuktitut: intransitive, transitive and antipassive.

\section{Intransitive}

Nanuq siniktuq.

$\begin{array}{llll}\text { nanuq } & -\phi & \text { sinik } & \text {-tuq } \\ \text { root } & \text { absolutive } & \text { root } & \text { indicative 3sg } \\ \text { (bear) } & & \text { (sleep) } & \text { intransitive }\end{array}$

The bear is sleeping.

\section{Transitive}

Angunasuktiup nanuq takujaa.

$\begin{array}{llllllll}\text { angu } & -n a s u k & -t i & -(u) p & \text { nanuq } & -\phi & \text { taku } & -j a a \\ \text { root } & \text { try } & \text { doer } & \text { relative } & \begin{array}{l}\text { root } \\ \text { (bear) }\end{array} & \text { abs } & \begin{array}{l}\text { root } \\ \text { indicative }\end{array} \\ \text { (catch up) } & & & & \text { (see) } & 3 \mathrm{sg} / 3 \mathrm{sg} \text { transitive }\end{array}$

The hunter sees the bear. 
Antipassive

$\begin{array}{lllllll}\text { Angunasukti nanurmik takuvuq. } & & & \\ \text { angu } & \text {-nasuk } & -t i & \text { nanuq } & \text {-mik } & \text { taku } & -v u q \\ \text { root } & \text { try } & \text { doer } & \text { root } & \text { modalis } & \text { root } & \text { indicative } \\ \text { (catch up) } & & & \text { (bear) } & & \text { (see) } & \text { 3sg intransitive }\end{array}$

The hunter sees a bear.

Semantically the difference in meaning which is created by the use of the antipassive versus the transitive usually corresponds to non-specificity versus specificity of the object.

There are two separate sets of pronoun suffixes to express transitivity and intransitivity and these combine with mood, number and person, forming extensive paradigms.

Mood can be divided into independent moods and dependent moods. The independent moods, the indicative, interrogative and imperative, function much like English.

The causative, conditional, dubitative and participal moods need a certain amount of explanation as to their usage.

In the causative and conditional moods switch reference distinguishes the third plain and third reflexive forms. The causative mood is used with sentences that can be translated with because in the present and future, when or because in past tense, and that in past and future.

Quviasukpunga tikimmat.

$\begin{array}{lllll}\text { quvia } & \text {-suk } & \text {-punga } & \text { tikit } & \text {-mat } \\ \text { root } & \text { intransitive } & \text { indicative } & \text { root } & \text { causative } \\ \text { (happy) } & \text { marker } & \text { 1sg intransitive } & \text { (arrive) } & \text { 4sg intransitive }\end{array}$

I'm happy because he arrived.

Nninngaumajuq arnarmik kuniksiniarami.

$\begin{array}{lllll}\text { ninngau } & -m a & -j u q & \text { arnaq } & -m i k \\ \text { root } & \text { in the } & \text { indicative } & \text { root } & \text { modalis } \\ \text { (angry) } & \text { state of } & \text { 3sg intransitive } & \text { (woman) } & \\ \text { kunik } & - \text { si } & \text {-niaq } & - \text { gami } & \\ \text { root } & \text { intransitive } & \text { general } & \text { causative } & \\ \text { (kiss) } & \text { marker } & \text { future } & \text { 3sg intransitive } & \end{array}$

$\mathrm{He} / \mathrm{she}$ is angry because he/she will kiss a woman.

Takulauqtara tikimmat.

$\begin{array}{lllll}\text { taku } & \text {-lauq } & \text {-tara } & \text { tikit } & - \text { mat } \\ \text { root } & \text { general } & \text { indicative } & \text { root } & \text { causative } \\ \text { (see) } & \text { past } & 1 \mathrm{sg} / 3 \mathrm{sg} \text { transitive } & \text { (arrive) } & \text { 3sg intransitive }\end{array}$

I saw him when he arrived.

Qaujimajara tikimmat.

$\begin{array}{lllll}\text { qauji } & - \text { ma } & \text {-jara } & \text { tikit } & \text {-mat } \\ \text { root } & \text { in the } & \text { indicative } & \text { root } & \text { causative } \\ \text { (know) } & \text { state of } & 1 \mathrm{sg} / 3 \mathrm{sg} \text { transitive } & \text { (arrive) } & \text { 4sg intransitive }\end{array}$

$\mathrm{I}$ know that he arrived.

The conditional is usually translated with "if". Care must be taken in future tenses as it can also be translated with "when" depending on context.

\begin{tabular}{llllll}
\multicolumn{2}{l}{ Quviasungniaqtunga tikippat } & & \\
quvia & - suk & -niaq & -tunga & tikit & -pat \\
root & intransitive & general & indicative & root & conditional \\
(happy) & marker & future & 1sg & (arrive) & 3sg \\
& & & intransitive & & intransitive
\end{tabular}


(I will be happy if he comes)

(I will be happy when he comes)

The participial is composed of two sets of participles, past and present, and future. In using the past and present participles, a subdivision is made between dependent and independent ones. Dependent participles must have the same subject as the main verb. They begin with a voiceless lateral slit fricative l. (After vowels there is an instrusive $b$ in some dialects, and the voiceless I becomes a voiced I). Independent participle is used when the participle subject is not the same as the main verb. It is marked by the addition of -tit- which is assimilated to -til.

\section{Siniktillunga anivutit.}

$\begin{array}{lllll}\text { sinik } & \text {-tit } & \text {-lunga } & \text { ani } & \text {-vutit } \\ \text { root } & \text { indicative } & \text { participial } & \text { root } & \text { indicative } \\ \text { (sleep) } & \text { part. marker } & \text { 1sg intransitive } & \text { (go out) } & \text { 2sg intransitive }\end{array}$

While I'm sleeping, you go out.

\section{Siniklunga anijunga.}

$\begin{array}{llll}\text { sinik } & \text {-lunga } & \text { ani } & \text {-junga } \\ \text { root } & \text { participial } & \text { root } & \text { indicative } \\ \text { (sleep) } & \text { 1sg intransitive } & \text { (go out) } & \text { 1sg intransitive }\end{array}$

While I'm sleeping, I go out.

\section{Itiqtillutit anijuq.}

$\begin{array}{lllll}\text { itiq } & \text {-tit } & \text {-lutit } & \text { ani } & \text {-juq } \\ \text { root } & \text { indicative } & \text { participial } & \text { root } & \text { indicative } \\ \text { (enter) } & \text { part. marker } & \text { 2sg intransitive } & \text { (go out) } & \text { 3sg intransitive }\end{array}$

While you were entering he went out.

The future participles begin with a voiced 1 .

\begin{tabular}{llllll}
\multicolumn{2}{l}{ Aqagu qailunga takuniaqpara. } & & & \\
aqagu & qai & -lunga & taku & -niaq & -para \\
adverb & root & participial & root & general & indicative 1sg/ \\
(tomorrow) & (come) & 1sg intransitive & (see) & future & 3sg transitive
\end{tabular}

Tomorrow, I will see it when I come.

The intransitive forms of the participial have two other uses.

The simple forms can be translated as 'when'. The reflexive can be translated as 'even though'. Both clauses must contain factual information.

\begin{tabular}{|c|c|c|c|c|}
\hline \multicolumn{5}{|c|}{ Aannialunga aullajjaanngilanga. } \\
\hline $\begin{array}{l}\text { aannia } \\
\text { root } \\
\text { (sick) }\end{array}$ & $\begin{array}{l}\text {-lunga } \\
\text { participial } \\
\text { 1sg intransitive }\end{array}$ & $\begin{array}{l}\text { aullaq } \\
\text { root } \\
\text { (go away) }\end{array}$ & $\begin{array}{l}\text {-jjaanngit } \\
\text { negative }\end{array}$ & $\begin{array}{l}\text {-langa } \\
\text { indicative } \\
\text { 1sg intransitive }\end{array}$ \\
\hline \multicolumn{5}{|c|}{ I won't go away when I'm sick. } \\
\hline \multicolumn{5}{|c|}{ Aannialarma aullarasukpunga. } \\
\hline $\begin{array}{l}\text { aannia } \\
\text { root } \\
\text { (sick) }\end{array}$ & $\begin{array}{l}\text {-larma } \\
\text { participial } \\
\text { 1sg intransitive }\end{array}$ & $\begin{array}{l}\text { aullaq } \\
\text { root } \\
\text { (go away) }\end{array}$ & $\begin{array}{l}\text {-rasuk } \\
\text { try }\end{array}$ & $\begin{array}{l}\text { punga } \\
\text { indicative } \\
\text { 1sg intransitive }\end{array}$ \\
\hline
\end{tabular}

Even though I'm sick, I'll try to go away.

The dubitative is used to express doubt, a question that is indirectly asked or when one is wondering if, why, how, where or when an event is happening. 
In Inuktitut, perceived and unperceived past actions are distinguished in the verbal system. The affix -niq- is used to describe the past unperceived in the state of the verb. The time of the past action is indicated by tense suffixes used with the verb in the subordinate clause.

Tingmisuuq tikilaunngittuq suuqaima katannirami.

\begin{tabular}{llllll} 
tingmisuuq & tikit & -lauq & -nngit & -tuq & suuqaima \\
root & root & general & negative & indicative & adverb \\
(airplane) & (arrive) & past & & 3sg intransitive & (of course) \\
katak & $-n i q$ & & - gami & & \\
root (crash) & past unperceived & -3sg causative intransitive & \\
\multicolumn{7}{l}{$\begin{array}{l}\text { The plane didn't arrive of course because it crashed. }\end{array}$}
\end{tabular}

The affix -viniq can also be added to the verb to show past action unperceived by the speaker at the time of its occurrence.

\begin{tabular}{llll}
\multicolumn{2}{l}{ Tigliktaviniit. } & & \\
tiglik & -ta & -viniq & - it \\
root & passive & past & indicative 2/3sg \\
(steal) & participle & unperceived & transitive
\end{tabular}

You stole it (unknown to me at the time).

Tigliktait.

$\begin{array}{lll}\text { tiglik } & - \text { taq } & -i t \\ \text { root } & \text { passive } & \text { indicative } \\ \text { (steal) } & \text { participle } & 2 \mathrm{sg} / 3 \mathrm{sg} \text { intransitive }\end{array}$

You stole it (and I knew about it at the time).

Past actions unperceived by the speaker at the time of their occurrence, but which became know to him/her later by being reported verbally are expressed by the speaker as if they were perceived with the addition of the word final suffix -guuq.

\section{Qimmuqsiit pingasut tikittuguuq.}

$\begin{array}{llllll}\text { qimmutsit } & \text {-it } & \text { pingasut } & \text { tikit } & \text {-tut } & \text {-guuq } \\ \text { root } & \text { plural } & \text { three } & \text { root } & \text { indicative } & \text { reported } \\ \text { (dog team) } & \text { marker } & \text { (arrive) } & 3 \text { plural intransitive } & \text { speech } & \end{array}$

Three dog teams arrived (they say).

I hope that this brief structural overview of Inuktitut provides a backdrop for the articles on interpreting and translating which follow.

Notes

1. L. J. Dorais (1990) Inuit Uqausiqatigiit: Inuit Languages and Dialect, Arctic College, Nunatta Campus, Iqaluit.

2. M. S. Sammons (1985) Inuktitut in Rankin Intet, UMI Ann Arbor, Michigan.

3. P. Denny (1982) "Semantics of the Inuktitut (Eskimo) Spatial Deictics", I.J.A.L., vol. 48, no 4, pp. 359-384. 